\title{
The role of university botanic gardens in implementing the third mission
}

\author{
Tatyana Chernysheva* \\ Novosibirsk State Technical University
}

\begin{abstract}
The paper reveals a new dimension of implementing the third mission of a university - through the activities rolled-out by Russian universities in their botanic gardens. For urban residents, botanic gardens, in addition to their main functions, are gradually becoming a place for integrating different population groups, from schoolchildren to pensioners. These public spaces conduct active educational policies aimed at many segments of a broader university community, taking into account the experience of regional environmental organizations and international Associations of Botanic Gardens. The author argues that the ecological vector is a priority for productive communication of a university with regional and global audiences at the site of its Botanic Garden, which becomes a measure of the university entering upon the way of sustainable development
\end{abstract}

\section{Contribution of botanic gardens to the development of regions}

Botanic gardens at universities contribute to fulfillment of the universities' third mission, understood as participation in developing their particular region [1].

The third mission involves improvement of the society, which is impossible without looking beyond the horizon, i.e., taking into account the needs of the future generations. Thus, the third mission is closely related to the concept of sustainable development, which focuses on conservation of the existing biological species on the Earth. Use of natural resources and investment patterns are based on rationale of human transformation [2]. University botanic gardens are not only a kind of protected areas for plant cultivation, but also represent communication platforms with many university audiences - preschoolers, schoolchildren, applicants, students, partners, competitors, representatives of the authorities and businesses, the media - allowing to maintain constant contacts with them. Botanic gardens at universities can serve as some podium to show the activities of the university and engage the local population. Typically, botanic gardens have memorial artefacts associated with significant milestones in the life of the university, its great figures, particularly, trees planted by them. The gardens are picturesque park complexes that attract both the residents and guests of a region. The annual attendance of botanic gardens at universities is tens of thousands people a year.

\footnotetext{
* Corresponding author: chernysheva@corp.nstu.ru
} 


\section{Activities of botanic gardens within the framework of the Sustainable Development Goals}

Harmonious relations between man and nature are becoming increasingly complicated in the context of ongoing urbanization. In this situation, botanic gardens can act as an intermediary, helping to form a new ecological thinking, which is necessary in all modern spheres of activity. Functions of university gardens concern many aspects of public life. The aim of the study is to discover the responsibilities of botanic gardens in relation to the third mission of universities, which is closely related to the concept of their sustainable development. The tasks are to identify specific practices of university botanic gardens and their relationship with the sustainable development goals, reveal social customs of Botanic Garden, and identify high-potential vectors of communication with regional communities. The object of the study covers some aspects of public relations of university botanic gardens, their sociocultural activity. The study methods include analyzing documentary sources in order to form an idea of the object of research in relation to its subject - the implementation of the university third mission.

First of all, it should be noted that botanic Gardens are institutions that have documented plants collections and use them for scientific research, conservation of the diversity of biological species, and display in order to consolidate the acquired knowledge [3]. It is logical that fulfillment of these goals is a university prerogative. Education and science are the first two missions of the university, and the third is relations with the society - the university botanic gardens are also managing it quite successfully nowadays.

Many outstanding universities are proud to have botanic gardens, which apart form research and economic take the form of centers for restoring physical and mental strength. Today, there are about 90 botanic Gardens in Russia, 40 of which are under the auspices of the Ministry of Higher Education [4, 5, 6].

The main tasks of the university botanic gardens are to develop methods for cultivating the gene pool of plants of local and world flora, their acclimatization and maintenance, especially rare and endangered species, as well as to conduct scientific and educational activities in the field of nature conservation, selection and cultivation of biological species and landscape design.

The main task of botanic gardens at universities, certainly, is to support the educational process.

Ornamental, vegetable and medicinal, fruit and berry plants grown in the gardens are used as living illustrations during lectures and practical classes with students -biologists and botanists - for their acquaintance with the vegetation of the subtropics, tropics, mountain, steppe and forest-steppe zones. They have the opportunity to see protected rare and endangered species of plants in the wild. However, students of other specialties agronomists, ecologists, geographers, foresters, designers and art historians - can also find here a base for obtaining the necessary knowledge. Botanic gardens of higher education institutions, which have faculties for training specialists in landscape design, landscape architecture, forestry, may initiate innovative startups for improvement of urban forest areas, landscaping of corporate and public facilities, modeling of new parks, as well as for decorative design of such premises as concert halls, cinemas, lofts, or co-working areas as part of contractual projects [7].

The educative and public functions of botanic gardens, albeit complementary, attract even more attention to the universities, making the society aware of their competitive advantages through exciting commercial and non-commercial programs. It is observed, that in the cities with university botanic gardens, the residents are exposed and began develop environmental comprehension since early childhood $[8,9]$.

Let's consider the services of botanic gardens provided by universities to the society. 


\section{Practices of university botanic gardens on implementing the third mission}

MSU Botanic Garden on Vorobyovy Gory always welcomes delegations of guests from different countries who are on a visit to the university, often unrelated to the flora. It is simply a beautiful and iconic place, through which a visitor can learn a lot about the activities of the University as a whole. The Botanic Garden caters to students, partners, and representatives of NGOs, for whom a lot of theme events are organized. Naturally, most of such activities are aimed at children. For example, the cycle of classes "Sprout" for children aged 4-11, where children are introduced to the diversity of the plant world, "Dillpolis" - classes in gardening and botany for children aged 7-11, where they are taught to grow vegetables and other useful plants, the "School of a young gardener" for children aged 13-16, where they learn gardening. The Botanic Garden offers birthday parties and other kids' animation programs - "Climbers in the world of plants", "In the footsteps of Gerda", "Journey to the Emerald City". Professional development programs -"Decorative Dendrology", "Openground Floriculture", "Practical fruit growing" - are intended for adults; and the Scientific and Educational Public Lecture Hall is open. The staff of the Gardens organizes seminars for teachers of elective subjects in floristics and phytodesign, give charity tours for the elderly, war and labor veterans, the disabled, children from large and low-income families, and orphans [10]. The branch of the Botanic Garden of Moscow State University "Aptekarsky Ogorod" [Apothecary Garden], founded by Peter I in 1706, holds annual flower festivals, concerts and master classes, many of its events are also charitable [11].

Also, the oldest Botanic Garden at a university are the Garden of St. Petersburg University, associated with an outstanding botanist Andrey Beketov, The Garden has five main areas of work. Firstly, educational programs aimed at mastering plant introduction, studying the basics and the necessary skills for landscape design and decorative gardening. Secondly, public events promoting the Botanic Garden, botanic knowledge and the basics of decorative gardening. Third, student and academic research. Fourth, cooperation with other Gardens in order to exchange experience in plant introduction and acclimatization as well as biodiversity conservation taking into account global warming. Fifth, the Botanic Garden for children (excursions, master classes, lessons at the "School of young gardeners"). Obviously, three of the five functions belong to the third mission spectrum - communication with the society.

Many volunteer projects of the University are carried out on the basis of the collection of living plants in greenhouses and in the open ground. Thus, environmental thinking is being formed intensively. The Botanic Garden contributed to the ecological focus of St. Petersburg State University ( $\mathrm{SPbU}$ ). The University has developed its own environmental policy, the basic principles of which are as follows: compliance with the environmental standards; establishing comfortable and harmless habitat for humans without deteriorating the surrounding nature; implementing international programs that explore the mutual influence in the "nature-society-human" ecosystem; preventing adverse impacts of any managerial decisions; transparency of the University's sustainable development efforts for outside audiences; comprehensive employment of the R\&D potential of University scholars in solving environmental tasks. These principles form the basis of SPbU Environmental Clinic, which provides consulting services on a broad range of environmental management problems. Guided by their lecturers, students conduct expert examinations, surveys and consultations in the field of Earth sciences (ecology, geoecology, hydrometeorology, geology, biology, land use, etc.); fulfill environmentally-focused research-to-practice projects; take part in awareness-raising educational activities, supervise events for different segments of the population and professional communities, attract and train volunteers [12]. 
The Siberian Botanic Garden of Tomsk State University became the first university garden in Siberia, where educational and awareness-raising activities were launched on the basis of the greenhouse complex by the specialized departments of Agronomy, Botany, Landscape Construction and Forestry of the Biological Institute of TSU. It offers both lectures and hands-on courses in "Greenhouse business", "Meadow Farming", "Fundamentals of Phytodesign", "Floriculture", "Plant Introduction", "History of Agriculture". In alliance with the faculty, however, environmental projects are also carried out by representatives of other faculties. For instance, students of the Faculty of Geology and Geography tested an eco-friendly method of processing plant waste as part of the "Grass in business" project that won the "People changing the world" contest organized by Sibur Holding. Every summer, dozens of tons of young green grass are taken to the landfill, so students decided to make a fertile soil from it, using an efficient composting technology when waste is recycled on site. The grass settings were treated with microbiological fertilizer, and California worms were settled in the other part. The result was an environmentally friendly fertilizer that can significantly improve the quality of urban lawns and flower beds.

TSU also has a pilot project "I live in the ECO format". Representatives of TSU Botanic Garden conduct seminars on noospheric-ecological thinking for pupils with disabilities (No.45 school in Tomsk) [13, 14, 15].

The Kaliningrad Botanic Garden at the Baltic Federal University (BFU) is divided into 4 units: tropical, subtropical, succulents and palms. The Garden has 6 greenhouses for heatloving plants, as well as flower beds, greenhouses and a small pond. Thirty-nine woody plants of the Botanic Garden are listed in the Red Books of different ranks.

Back in the early $20^{\text {th }}$ century, the purpose of founding the Garden was to teach botany to schoolchildren and adult gardening enthusiasts. In addition, the Garden immediately became the base of landscaping in Konigsberg. Every year, students hold thematic events in Kant Botanic Garden to mark the calendar holidays and flowering of various plants. The most popula holidays for the residents and guests of the city and the university to visit the Gardens are the "Family Day" with concerts and master classes, the "Spring Day" or the "Bird Day" on April 1; the "Summer Holiday", dedicated to rose flowering; and the "Autumn Holiday" with thematic excursions.

The Botanic Garden of the BFU is awarded an honorary "Green Flag" - a global environmental symbol, a sign of the quality of environmental education, confirming that a university is actively engaged in shaping eco-culture. The goal of the Green Flag program is to form an understanding of the concept of sustainable development across the young generation, foster resource and energy saving skills, promote communication and collaboration with local communities, and help enunciate an environmental code of conduct. BFU has been maintaining robust cooperation with the "Green Flag".

Every year, the Botanic Garden hosts a variety of guided tours. As a member of the Council of Botanic Gardens of Russia, the BFU Garden cooperates with other botanic gardens from universities all over the world, exchanging technologies on growing particular crops and plant seeds. Events dedicated to specific flowers and trees are regularly announced, for example, "Tulip Tree Day", "Tea Rose Day", "Magnolia Day", "Spruce Day", co-working tours for primary schoolers - "Rare plants", "Green Pharmacy", "Our pets", "Visiting the woodpecker and squirrel" [16].

The Botanic Garden of Irkutsk State University has initiated a project on horticultural rehabilitation for difficult teenagers, who then form the core of the assistant volunteers of the Botanic Garden. The Garden is home to various art schools, schools of applied arts, schools of "ikebana" and "bonsai" [17].

Environmental campaigns and pageants involving pupils from secondary schools under the patronage of Tver State University - such as "Children in support of birds", "In the interests of the Earth" - have become traditional at the University Botanic Garden. At the 
end of the events, students make crafts from plant materials in the Garden, organize performances, design models how distant future gardens will look like, write essays, and do research projects under the guidance of their mentors [18, 19].

In the Botanic Garden of Ivanovo State University, innovative technologies of environmentally friendly vegetable growing, floriculture, and horticulture are being introduced. An exemplary vegetable garden and fruit garden can be found here. The emphasis is on conservation and the maximum use of local plant resources, which are essential for survival of the population in the region. Consultations are held for large and low-income families: within the framework of the "Decent Survival" project, recommendations are given on a proper health-saving diet [20].

\section{The role of botanic gardens in providing services to the population in a territory}

The third mission involves: 1) technology transfer, 2) continuing education, and 3) social engagement. It should be emphasized that botanic gardens at universities are able to implement all these functions successfully, establishing contacts with representatives of almost all groups of the public. Technology transfer comprises innovations concerning plant introduction in regions, cultivating seeds, and employing unique practices of growing vegetable, fruit and medicinal plants with an emphasis on local species, supplying seeds to the interested parties. University botanic gardens try to sell the produce they grow, but also share it and all kinds of planting material with shelters, boarding schools, nursing homes, kindergartens and schools.

Continuing education includes diverse training programs discussed above, that are aimed at different audiences in a region, including adults and the elderly. Social engagement is manifested in the abundance of environmental activities implemented on the grounds of botanic gardens with regard to the genetic diversity of plant species and the threat of losing them. University botanic gardens provide many useful services to the population, for example, they create projects for landscaping the interiors and exteriors of various regional companies, improve urban areas that can be used for recreation of the residents, make flower arrangements for public landmark university events. Employees of botanic gardens do research, take an active part in international, regional and city workshops and exhibitions, as well as speak out in the media. Thus, effective activity of botanic gardens at universities makes a considerable contribution to fulfillment of their third mission - integration with the society.

\section{References}

1. T.L. Chernysheva, The Third Mission of the University: Technologies for the Formation of Thinking in Modern Students (2020)

2. Report of the World Commission on Environment and Development: Our Common Future (1987), https://sustainabledevelopment.un.org/

3. S.P. Dunn, Plant Diversity, 39, 396 (2017).

4. M. Pavlova, International Journal of Technology and Design Education, 23(3), 733 (2013)

5. M.S. Yamburov, Botanical Gardens as Centers for Study and Conservation of PhytoDiversity: Proceedings of the VII International conference, dedicated to the 140th anniversary of the Siberian Botanical Garden of Tomsk State University, 5 (2020)

6. H. Kopnina, Environmental Education Research, 18(5), 699 (2012) 
7. G. Chen, W. Sun, Plant Diversity, 40, 181 (2018)

8. Organisation for Economic Co-operation and Development (OECD). Global competency for an inclusive world (2016), https://www.oecd. org/

9. F. Rauch, R. Steiner, CEPS Journal, 3(1), 9 (2013)

10. Botanical Garden, Faculty of Biology, Moscow State University Lomonosov, https://botsad.msu.ru/

11. Lomonosov Moscow State University Botanical Garden "Aptekarsky gorod", https://hortus.ru/

12. Saint Petersburg State University, https://spbu.ru/

13. Siberian Botanical Garden, http://sibbs.tsu.ru/

14. I.A. Dubinsky, S.A. Nekrylov, S.F. Fominykh, Bulletin of Tomsk State University, 409, 55 (2016)

15. T.P. Astafurova, A.S. Prokopyev, T.N. Belyaeva, Problems of studying the vegetation cover of Siberia: materials of the V International Scientific Conference, dedicated to the 130th anniversary of the P.N. Krylov Herbarium and the 135th anniversary of the Siberian Botanical Garden of Tomsk State University, 12 (2015)

16. Botanical Garden of the Immanuel Kant Baltic Federal University, https://old.kantiana.ru/garden/

17. Botanical Garden Irkutsk State University, http://bg.isu.ru/ru/index.html

18. Botanical Garden of Tversk State University, http://garden.tversu.ru/

19. L.R. Sharafieva, Green Journal-Bulletin of the Botanical Garden of Tver State University, 6, 3 (2019)

20. Interactive travel portal, http://in3p.ru/ 